\title{
Boletoid fungi (Boletaceae, Basidiomycota) of protected areas of Kon Tum Plateau (Central Highlands of Vietnam)
}

\author{
T. H. G. Pham ${ }^{1,4}$, O. V. Morozova ${ }^{2,5 *}$, A. V. Alexandrova ${ }^{1,3,6}$ \\ ${ }^{1}$ Joint Russian-Vietnamese Tropical Research and Technological Center, Nguyen Van Huyen Str., 63, Cau Giay, Hanoi, Vietnam \\ ${ }^{2}$ Komarov Botanical Institute of the Russian Academy of Sciences, Prof. Popova Str., 2, Saint Petersburg, 197376, Russia \\ ${ }^{3}$ Lomonosov Moscow State University, Leninskie Gory Str., 1, 12, Moscow, 119234, Russia \\ ${ }^{4}$ ORCID iD: https://orcid.org/0000-0002-4137-7213 \\ ${ }^{5}$ E-mail: ovm.leptonia@gmail.com; ORCID iD: https://orcid.org/0000-0002-7329-528X \\ ${ }^{6}$ ORCID iD: https://orcid.org/0000-0003-2359-4780
}

Keywords: biodiversity, boletoid basidiomycetes, Central Highlands of Vietnam, Kon Chu Rang, Kon Ka Kinh, Kon Plong, Tây Nguyên, tropical forests.

Summary. The article continues the series of publications devoted to the boletoid fungi of Vietnam. It summarizes the results of the observation of their diversity in three nature protected areas of the Central Highlands (Tây Nguyên) Kon Ka Kinh National Park, Kon Chu Rang (Kon Chư Răng) Nature Reserve and Kon Plong Protected Forest, where middle-mountain evergreen broad-leaved and coniferous-deciduous forests prevail at altitudes of 900-1500 m. An annotated list of 22 revealed species is presented. Of these, two species (Fistulinella aurantioflava and Tylopilus subotsuensis) have been recently described from this territory as new to science. Hortiboletus rupicapreus is reported "ad interim". Information on eight species (Aureoboletus sinobadius, Hourangia nigropunctata, Ionosporus longipes, Neoboletus multipunctatus, Phylloporus luxiensis, Pulveroboletus subrufus, Tylopilus atripurpureus, T. atroviolaceobrunneus) is published for the first time for Vietnam. Strobilomyces aff. echinocephalus, S. aff. glabriceps, and Tylopilus aff. balloui (two different lines) are close to known species but genetically not identical. Six more specimens are identified only to the genus, and they probably represent species new to science. The color photographs of new to Vietnam and noteworthy species are presented. The nucleotide sequences obtained during the study were deposited in NCBI GenBank.

\section{Болетовые грибы (Boletaceae, Basidiomycota) особо охраняемых природных территорий плато Контум (Центральное нагорье Вьетнама)}

\author{
Т. Х. Ж. Фам ${ }^{1}$ О. В. Морозова ${ }^{2}$ А. В. Александрова ${ }^{1,3}$ \\ ${ }^{1}$ Совместный Российско-Вьетнамский Тропический научно-исследовательский и технологический иентр, \\ ул. Нгуен Ван Хуен, д. 63, Кау Зай, г. Ханой, Вьетнам \\ ${ }^{2}$ Ботанический институт им. В. Л. Комарова РАН, ул. Проф. Попова, д. 2, г. Санкт-Петербург, 197376, Россия \\ ${ }^{3}$ Московский государственный университет им. М. В. Ломоносова, Биологический факультет, 119234, \\ Ленинские горы, д. 1, стр. 12, г. Москва, Россия
}

Ключевые слова: биоразнообразие, болетоидные базидиомицеты, Конкакинь, Конплонг, Контьыранг, особо охраняемые природные территории, тропические леса, Тэйнгуэн, Центральное нагорье Вьетнама. 


\begin{abstract}
Аннотация. Статья продолжает серию работ, посвященных болетовым грибам Вьетнама. Здесь обобщены результаты изучения разнообразия этой группы грибов трех охраняемых природных территорий Центрального нагорья (Тэйнгуэн) - национального парка Конкакинь, природного заповедника Контьыранг и охраняемого лесного массива Конплонг, где на высотах 900-1500 м преобладают среднегорные широколиственные и хвойно-широколиственные леса. Приводится аннотированный список 22 идентифицированных видов. Из них два недавно описаны с этой территории как новые для науки виды (Fistulinella aurantioflava и Tylopilus subotsuensis). Hortiboletus rupicapreus приводится "ad interim”. Информация о восьми видах (Aureoboletus sinobadius, Hourangia nigropunctata, Ionosporus longipes, Neoboletus multipunctatus, Phylloporus luxiensis, Pulveroboletus subrufus, Tylopilus atripurpureus, T. atroviolaceobrunneus) публикуется впервые для Вьетнама. Strobilomyces aff. echinocephalus, S. aff. glabriceps и Tylopilus aff. balloui незначительно отличаются генетически от соответствующих известных видов. Еще шесть образцов определены только до рода и, вероятно, представляют новые для науки виды. Приводятся цветные фотографии новых для Вьетнама и редких видов. Нуклеотидные последовательности, полученные в ходе исследования, депонированы в GenBank NCBI.
\end{abstract}

\section{Introduction}

This article continues the series of publications devoted to the diversity of the boletoid fungi in Vietnam (Pham et al., 2018; Pham, Morozova, 2020). The results of the work in three nature protected areas of the Central Highlands (Tây Nguyên) - Kon Chu Rang (Kon Chư Răng) Nature Reserve, Kon Ka Kinh National Park and Kon Plong Protected Forest - are summarized here. Before the beginning of our research, there was no information on the mycobiota of this territory. Then, the data on the agaricoid genera Entoloma, Volvariella, Pluteus were published (Morozova et al., 2018; Malysheva et al., 2019, 2020).

An annotated list of 22 species of Boletaceae is presented here. Of these, two species (Fistulinella aurantioflava and Tylopilus subotsuensis) have been recently described by us from this territory as new to science (Crous et al., 2020, 2021). Hortiboletus rupicapreus is reported here "ad interim", it will be published soon. Eight species (Aureoboletus sinobadius, Hourangia nigropunctata, Ionosporus longipes, Neoboletus multipunctatus, Phylloporus luxiensis, Pulveroboletus subrufus, Tylopilus atripurpureus, and T. atroviolaceobrunneus) are published for the first time for Vietnam. But most of them (by the exclusion of Aureoboletus sinobadius and Tylopilus atripurpureus) were reported previously in the manuscript of the dissertation work of the first author (Pham, 2020).

\section{Materials and methods}

Collections were made by route method in different types of tropical forests on Kon Tum plateau in 2015-2017 in course of the investigation of mycobiota of the Central Highlands (Tây Nguyên).
The information on the nature conditions of the territories studied is provided below.

\section{Kon Ka Kinh National Park}

Kon Ka Kinh National Park (Vườn quốc gia Kon Ka Kinh) is located in the northern part of Gia Lai Province (Mang Yang County, A Yun Commune) between $14.15^{\circ} \mathrm{N}-14.5^{\circ} \mathrm{N}$ and $108.25^{\circ} \mathrm{E}-108.45^{\circ} \mathrm{E}$ and covers an area of $417.8 \mathrm{~km}^{2}$. About $80 \%(331.46$ $\mathrm{km}^{2}$ ) of the park's territory is covered with forests. The territory of the park lies between Pleiku and Kon Ha Nung plateaus and has mountainous terrain with an average altitude of $1200-1500 \mathrm{~m}$ a. s. 1. (the highest Kon Ka Kinh - 1748 m). The rivers flowing through the park belong to the basins of the $\mathrm{Ba}$, Pne, and A Yun rivers. The park's climate is tropical monsoon, with distinct rainy (May - November) and dry (December - April) seasons. The average annual temperature ranges from 21 to $25{ }^{\circ} \mathrm{C}$. The average annual precipitation is from 2000 to 2500 $\mathrm{mm}$, the peak of precipitation falls in July-August $(400-450 \mathrm{~mm})$. There is practically no precipitation in January - February (Sourcebook of Existing ..., 2004; Ha et al., 2011, 2014).

The forest vegetation of Kon Ka Kinh National Park is represented by three main types (Thai, 1978; Le et al., 2000). The most widespread are mountain evergreen broad-leaved forests, which occupy heights of 900-1000 m a. s. 1. and higher. They are characterized by the dominance of species of Fagaceae (Castanopsis, Lithocarpus, Quercus), Lauraceae, Euphorbiaceae, Meliaceae, Sterculiaceae, Theaceae, Rubiaceae. In mountain evergreen mixed forests found south of the Kon Ka Kinh Mt, at altitudes from $1300 \mathrm{~m}$, in addition to species from the families Fagaceae, Theaceae, Euphorbiaceae, Hamamelidaceae, Elaeocarpaceae, Myrtaceae, and Meliaceae, species of conifers present (Fokienia hodginsii, Dacrycarpus imbricatus, Dacrydium 
elatum, Nageia fleuryi, Podocarpus neriifolius). Below $900 \mathrm{~m}$ a. s. 1., low-mountain evergreen broad-leaved forests are developed, dominated by Dipterocarpaceae (Shorea siamensis, S. roxburghii), Fabaceae, Irvingiaceae, Euphorbiaceae, Moraceae, Burseraceae, Lauraceae, Apocynaceae, Meliaceae, Fagaceae, and Magnoliaceae. Rather large area is occupied by plantings of Pinus latteri.

\section{Kon Chu Rang Nature Reserve}

The KBTTN Kon Chu Răng is located in the northeastern part of Gia Lai Province (K'Bang District, Son Lang Commune), between $14.5^{\circ} \mathrm{N}-14.58^{\circ} \mathrm{N}$ and $108.5^{\circ} \mathrm{E}-108.65^{\circ} \mathrm{E}$, and is bordered by the provinces of Binh Dinh, Quang Ngai, and Kon Tum. The area of the reserve is 159 $\mathrm{km}^{2}$, of which $156.1 \mathrm{~km}^{2}$ (99\%) are primary and intact forests. The relief of the reserve is mostly hilly, mountainous in the northern part, with heights from 800 to 1452 m a. s. 1. (Kon Chư Răng). The average annual temperature is about $21{ }^{\circ} \mathrm{C}$ (maximum in May $+28{ }^{\circ} \mathrm{C}$, minimum in January $+12{ }^{\circ} \mathrm{C}$ ). The average annual precipitation is about $1900-2000$ $\mathrm{mm}$, the peak of precipitation falls in September $(340 \mathrm{~mm})$. The dry season is relatively short, with up to $60 \mathrm{~mm}$ of precipitation per month in January April (New et al., 2002; Sourcebook of Existing ..., 2004). Numerous rivers flowing through the reserve belong to basin of the Kon River (Sông Kôn), which has a number of waterfalls, the most famous and tallest of which is $50 \mathrm{~m}$ high.

The main forest type is middle-mountain evergreen broad-leaved and mixed forest distributed at elevations between 900 and $1500 \mathrm{~m}$ in the northwest of the nature reserve. Canopy cover of this forest type is 70 to $80 \%$, and the tree flora is dominated by species from the Fagaceae (Lithocarpus, Quercus, Castanopsis), Lauraceae, Fabaceae, Clusiaceae, Myrtaceae, Ericaceae, Burseraceae, and Magnoliaceae, mixed with gymnosperms (Dacrycarpus imbricatus, Dacrydium elatum). Lowland evergreen forest occurs at elevations below $900 \mathrm{~m}$. Only $2 \%$ of the nature reserve is covered by secondary vegetation, mainly scrub with scattered trees.

\section{Kon Plong Protected Forest}

The Kon Plong Protected Forest is located in the northeast of Kon Tum Province (Kon Plong County), within the state forestry enterprises of Mang Canh II, Tan Lap, and the Ngok tem (Ngọk tem) Water Protection Forest. The massif has an area of 650.8 $\mathrm{km}^{2}$ and is located on the highly dissected mountain basalt plateau Kon Ha Nung (Kon Hà Nừng), at an altitude of 1100 to $1757 \mathrm{~m}$ a. s. 1. The studied territory is located in the basin of the Lo (Đắk Lo), Te (Nước Che) rivers and the lower reaches of the Khe (Đắk Khê) river within $14.7125^{\circ} \mathrm{N}-14.7589^{\circ} \mathrm{N}$ and $108.3^{\circ} \mathrm{E}-108.3233^{\circ} \mathrm{E}$. The climate is characterized by moderate temperatures (average annual temperature is about $+18{ }^{\circ} \mathrm{C}$, and the coldest month $+16{ }^{\circ} \mathrm{C}$ ) and heavy rainfall (up to $2800 \mathrm{~mm}$ per year).

The vegetation cover above $1000 \mathrm{~m}$ a. s. 1 . is dominated by middle-mountain evergreen mixed forests, the upper tier of which is dominated by Fagaceae (Lithocarpus, Quercus, Castanopsis), Lauraceae, Hamamelidaceae, Theaceae, Podocarpaceae (Dacrycarpus imbricatus, Dacrydium elatum, Podocarpus neriifolius), Pinaceae (Pinus dalatensis, Keteleeria evelyniana), Cupressaceae (Fokienia hodginsii), etc. There are areas of monodominant coniferous forests with Pinus latteri. At altitudes up to $900-1000 \mathrm{~m}$ a. s. 1. low-mountain evergreen broadleaf forests are developed with the participation of Dipterocarpaceae (Shorea siamensis, Parashorea stellata, Dipterocarpus obtusifolius), Fagaceae, Myrtaceae, Sterculiaceae, Annonaceae, etc. On a large area, natural forests are disturbed by economic activity and are replaced by secondary forests, bamboo, shrub and herbaceous communities (Eames et al., 2001; Pham et al., 2001).

\section{Morphological study}

Macromorphological features were studied on the basis of fresh and dried material, as well as through the analysis of photographs and descriptions taken in the field.

Micromorphological structures were studied using herbarium material. The collected specimens were examined using light and electron microscopy, as well as by analyzing DNA sequences (ITS and tefla sites). Microscopical characters were studied with a light Zeiss Axioscope A1 microscope with AxioCam1Ce 3 camera and program tools AxioVisionRel.4.6. (Carl Zeiss, Germany). Basidiospores, basidia, and hymenial cystidia were observed in squash preparations of small parts of the tubes in $5 \% \mathrm{KOH}$. The pileipellis was examined on a radial section of the pileus, the stipitipellis - on longitudinal slice of the stipe in $5 \% \mathrm{KOH}$. Basidiospore dimensions are based on 20 measurements, whereas cystidia and basidia dimensions are based on observing at least 10 structures per collection. 
SEM photos were also used for the identification of material. They have been made by L. A. Kartseva on a scanning analytical electron microscope JEOL JSM-6390LA of Core Facility Centre 'Cell and Molecular Technologies in Plant Science' of Komarov Botanical Institute and by A. V. Alexandrova (Lomonosov State University) on scanning analytical electron microscopes JSM6380LA and Camscan-S2 (Cambridge Instruments, 1990).

\section{Molecular-genetic study}

The molecular study is based on a phylogenetic species recognition (Taylor et al., 2000). To assess the taxonomic status of the identified phylogenetic lineages and put forward species hypotheses, we relied on the accepted boundaries of the possible variability of the ITS1-5.8S-ITS2 and tefl $\alpha$ nDNA regions within the species (Petersen et al., 2008; Hughes et al., 2009).

DNA was extracted from herbarium material using NucleoSpin ${ }^{\circledR}$ Plant II kit (Macherey-Nagel, Düren, Germany). The ribosomal ITS1-5.8SITS2 region was amplified with primers ITS1F and ITS4B (Gardes, Bruns, 1993), and elongation translation factor (tefla) - with Boletaceae-specific primers EF1-B-F1 and EF1-B-R (Wu et al., 2014). PCR products were purified with the Fermentas Genomic DNA Purification Kit (Thermo Fisher Scientific, Waltham, MA) and sequenced on an ABI model 3130 Genetic Analyzer (Applied Biosystems, Waltham, MA). Raw data were edited and assembled in MEGA X (Kumar et al., 2018). Newly generated sequences were deposited in NCBI GenBank (Table).

Collections studied are kept in the Mycological Herbarium of the Komarov Botanical Institute (LE).

\section{Results and discussion}

Twenty-two species revealed in the Kon Tum plateau are listed below including ten species published for the first time for Vietnam (marked with “!”).

Annotated list of species of Boletoid fungi of the Kon Chu Rang Nature Reserve, Kon Ka Kinh National Park, and Kon Plong Protected Forest Yang

Subfamily Austroboletoideae G. Wu et Zhu L.

Fistulinella aurantioflava T. H. G. Pham, A. V. Alexandrova et O. V. Morozova: "Kon Ka
Kinh National Park, $14.217129^{\circ} \mathrm{N}, 108.310132^{\circ} \mathrm{E}$, $1220 \mathrm{~m}$ a. s. 1., on slopes of mountain, on soil in the tropical mountain polydominant forest with the participation of Myrtaceae, Meliaceae, Anacardiaceae, Fagaceae, Theaceae. 16 V 2016. A. V. Alexandrova" (LE 315616) (Pham, 2020, as "Pulveroboletus" curtisii; Crous et al., 2021).

\section{Subfamily Boletoideae Burnett}

Hortiboletus rupicapreus Svetash., A. V. Alexandrova, O. V. Morozova et T. H. G. Pham, ad interim: "Kon Ka Kinh National Park, 14.219917º N, $108.325667^{\circ} \mathrm{E}, 1200 \mathrm{ma}$. s. 1., ridges on slopes, on soil in tropical mountain forests dominated by Myrtaceae, Meliaceae, Anacardiaceae, Fagaceae, Theaceae. 18 V 2016. A. V. Alexandrova" (LE 312677); ibid., “14.205190 ${ }^{\circ} \mathrm{N}, \quad 108.316312^{\circ} \mathrm{E}, 1000 \mathrm{~m}$ a. s. 1., on soil in plantations of Pinus kesiya with some Fagaceae. 15 V 2016. A. V. Alexandrova" (LE 312678).

Porphyrellus nigropurpureus (Hongo) Y. C. Li et Zhu L. Yang: "Kon Plong Protected Forest, Mang Canh Commune, $5 \mathrm{~km}$ north of Kondu Village, $14.73295^{\circ} \mathrm{N}, 108.31203^{\circ} \mathrm{E}, 1100 \mathrm{~m}$ a. s. 1 ., on soil in polydominant rainforest with participation of Podocarpaceae, Magnoliaceae, Myrtaceae, Calophyllaceae, Elaeocarpaceae. 10 VI 2016. O. V. Morozova" (LE 315621).

! Strobilomyces aff. echinocephalus Gelardi et Vizzini: "Kon Ka Kinh National Park, $14.219917^{\circ} \mathrm{N}$, $108.325667^{\circ} \mathrm{E}, 1200 \mathrm{~m}$ a. s. 1., ridges on slopes, on soil in tropical mountain forests dominated by Myrtaceae, Meliaceae, Anacardiaceae, Fagaceae, Theaceae. 18 V 2016. O. V. Morozova" (LE 312681 , fig. 1a, b).

! Strobilomyces aff. glabriceps W. F. Chiu: "Kon Ka Kinh National Park, on slopes of the mountain, $14.217129^{\circ} \mathrm{N}, 108.310132^{\circ} \mathrm{E}, 1220 \mathrm{~m}$ a. s. 1. , on soil in tropical mountain polydominant forest with the participation of Myrtaceae, Meliaceae, Anacardiaceae, Fagaceae, Theaceae. 16 V 2016. O. V. Morozova" (LE 312682, fig. 1c).

Strobilomyces seminudus Hongo: "Kon Ka Kinh National Park, $14.20414^{\circ} \mathrm{N}, 108.32143^{\circ} \mathrm{E}, 970$ $\mathrm{m}$ a. s. 1., on soil in a middle-mountain evergreen broadleaf forest with the participation of families Magnoliaceae, Myrtaceae, Theaceae, Lauraceae, Fagaceae. 20 V 2016. O. V. Morozova" (LE 315628 , fig. 1d, e, f).

! Tylopilus atripurpureus (Corner) E. Horak: "Kon Ka Kinh National Park, $14.20414^{\circ}$ N, $108.32143^{\circ} \mathrm{E}, 970 \mathrm{~m}$ a. s. 1 , on soil in a middlemountain evergreen broadleaf forest with the 
participation of families Magnoliaceae, Myrtaceae, in a tropical middle-mountain polydominant forest Theaceae, Lauraceae, Fagaceae. 20 V 2016. O. V. with a predominance of tree families Myrtaceae, Morozova" (LE 312683, fig. 1g).

Meliaceae, Fagaceae, Dipterocarpaceae. 15 V 2016.

! Tylopilus atroviolaceobrunneus Yan $\mathrm{C}$. Li et O. V. Morozova" (LE 315627, fig. 1h).

Zhu L. Yang: "Kon Ka Kinh National Park, on soil

Table

Boletaceae species in the nature protected areas studied, with voucher and Genbank numbers

\begin{tabular}{|c|c|c|c|c|c|c|c|}
\hline \multirow[b]{2}{*}{ Species } & \multicolumn{3}{|c|}{$\begin{array}{c}\text { Protected } \\
\text { areas }\end{array}$} & \multirow[b]{2}{*}{$\begin{array}{l}\text { Alt. } \\
\text { (m) }\end{array}$} & \multirow[b]{2}{*}{ LE numbers } & \multicolumn{2}{|c|}{ GenBank numbers } \\
\hline & 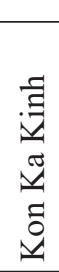 & 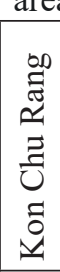 & 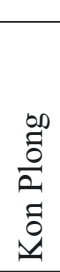 & & & ITS & tefla \\
\hline Aureoboletus sinobadius & + & & & 1220 & LE 312680 & MZ451340 & MZ424885 \\
\hline Boletellus areolatus & + & & + & $\begin{array}{c}980 \\
1030 \\
\end{array}$ & $\begin{array}{l}\text { LE } 315577 \\
\text { LE } 315576 \\
\end{array}$ & $\begin{array}{l}\text { MZ451341 } \\
\text { MZ451342 }\end{array}$ & $\begin{array}{l}- \\
- \\
\end{array}$ \\
\hline Boletus sp. 1 & + & & & 1300 & LE 312687 & MZ451343 & - \\
\hline Boletus sp. 2 & + & & & 1050 & LE 312698 & MZ451344 & - \\
\hline Chalciporus sp. 1 & + & & & 1000 & LE 312688 & MZ451345 & MZ424888 \\
\hline Chalciporus sp. 2 & & + & & 1000 & LE 312689 & MZ451346 & MZ424889 \\
\hline Chiua viridula & + & + & & 1000 & $\begin{array}{l}\text { LE } 315611 \\
\text { LE } 315612 \\
\end{array}$ & $\begin{array}{c}\text { MZ451347 } \\
-\end{array}$ & $\begin{array}{c}\text { MZ424887 } \\
- \\
\end{array}$ \\
\hline Crocinoboletus rufoaureus & & & + & 1280 & $\begin{array}{l}\text { LE } 315607 \\
\text { LE } 315561\end{array}$ & $\begin{array}{l}- \\
-\end{array}$ & $\begin{array}{c}- \\
\text { MZ424876 } \\
\text { (from Bidoup } \\
\text { - Nui Ba NP) }\end{array}$ \\
\hline Fistulinella aurantioflava & + & & & 1220 & LE 315616 & MW784159 & - \\
\hline Hortiboletus rupicapreus & + & & & $\begin{array}{l}1000 \\
1200\end{array}$ & $\begin{array}{l}\text { LE } 312677 \\
\text { LE } 312678\end{array}$ & $\begin{array}{l}\text { MW784161 } \\
\text { MW784162 }\end{array}$ & $\begin{array}{l}\text { MZ424893 } \\
\text { MZ424894 }\end{array}$ \\
\hline Hourangia nigropunctata & + & & & 1270 & LE 315626 & MZ451348 & - \\
\hline Ionosporus longipes & & + & & 1000 & LE 315589 & MZ451349 & MZ424890 \\
\hline Neoboletus multipunctatus & + & & & $\begin{array}{c}830 \\
1080 \\
1280\end{array}$ & $\begin{array}{l}\text { LE } 315625 \\
\text { LE } 312474 \\
\text { LE } 315637\end{array}$ & $\begin{array}{c}\text { MZ451350 } \\
\text { MZ451351 } \\
-\end{array}$ & $\begin{array}{l}- \\
- \\
-\end{array}$ \\
\hline Neoboletus obscureumbrinus & + & & & 1090 & LE 315548 & MZ451352 & MZ424891 \\
\hline Phylloporus luxiensis & + & & & 1020 & LE 315622 & - & MZ424877 \\
\hline Phylloporus rubiginosus & + & & & 1000 & LE 315623 & MZ451353 & - \\
\hline Phylloporus sp. 1 & & + & & 1000 & LE 312684 & - & MZ424892 \\
\hline Phylloporus sp. 2 & & & + & 1020 & LE 312685 & MZ451354 & - \\
\hline Porphyrellus nigropurpureus & & & + & 1100 & LE 315621 & - & MZ424878 \\
\hline Pulveroboletus subrufus & + & & & 1050 & LE 312686 & MZ451355 & MZ424879 \\
\hline Strobilomyces aff. echinocephalus & + & & & 1200 & LE 312681 & - & MZ424880 \\
\hline Strobilomyces aff. glabriceps & + & & & 1220 & LE 312682 & - & MZ424881 \\
\hline Strobilomyces seminudus & + & & & 970 & LE 315628 & MZ451356 & - \\
\hline Tylopilus atripurpureus & + & & & 970 & LE 312683 & - & MZ424884 \\
\hline Tylopilus atroviolaceobrunneus & + & & & 1000 & LE 315627 & - & MZ424882 \\
\hline Tylopilus aff. balloui 1 & + & & & 1300 & LE 312532 & MZ451357 & MZ424883 \\
\hline Tylopilus aff. balloui 2 & & + & & 1000 & LE 312700 & MZ451358 & MZ424886 \\
\hline Tylopilus subotsuensis & & + & & 1000 & LE 312527 & - & MW014272 \\
\hline \multirow[t]{2}{*}{ Total } & 20 & 6 & 4 & & & & \\
\hline & \multicolumn{3}{|c|}{28} & & & & \\
\hline
\end{tabular}



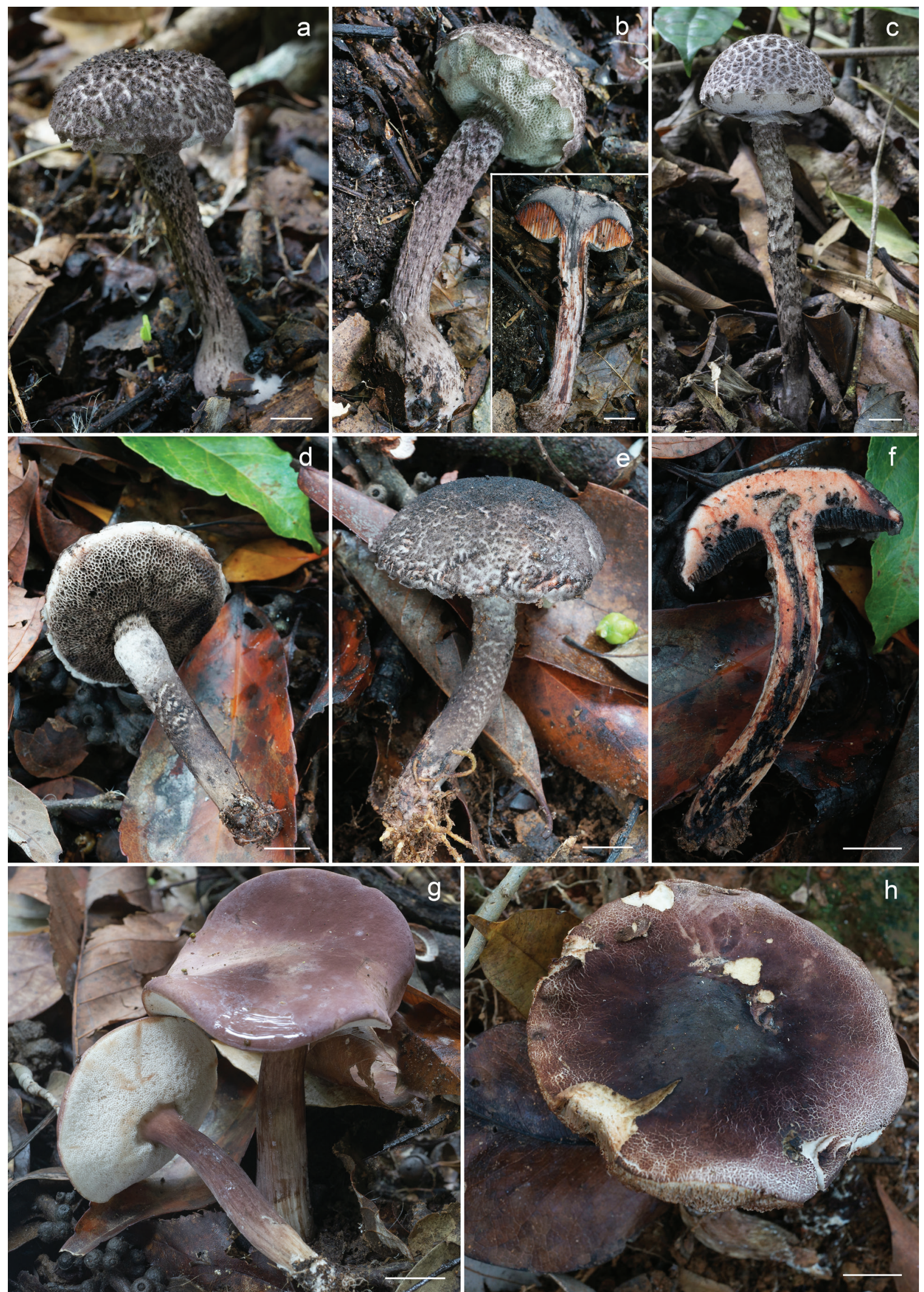

Fig. 1. Basidiomata in situ: a, b - Strobilomyces aff. echinocephalus (LE 312681); c - Strobilomyces aff. glabriceps (LE 312682); d, e, f-Strobilomyces seminudus (LE 315628); g - Tylopilus atripurpureus (LE 312683); h - Tylopilus atroviolaceobrunneus $(\mathrm{LE} 315627)$; scale bar $=1 \mathrm{~cm}$. 
! Tylopilus aff. balloui [1] (Peck) Singer: "Kon Ka Kinh National Park, $14.21988^{\circ}$ N, $108.30936^{\circ} \mathrm{E}$, $1300 \mathrm{~m}$ a. s. 1., on the soil in a tropical mountain polydominant forest with the participation of Myrtaceae, Meliaceae, Anacardiaceae, Fagaceae, Theaceae. 20 V 2016. A. V. Alexandrova" (LE 312532).

! Tylopilus aff. balloui [2] (Peck) Singer: "Kon Chu Rang Nature Reserve, $14.50516^{\circ} \mathrm{N}$, $108.58140^{\circ} \mathrm{E}, 1000 \mathrm{~m}$ a. s. 1 ., on soil in middlemountain evergreen mixed forest. $27 \mathrm{~V} 2016$. A. V. Alexandrova" (LE 312700).

Tylopilus subotsuensis T. H. G. Pham, A. V. Alexandrova et O. V. Morozova: "Kon Chu Rang Nature Reserve, $14.50042^{\circ} \mathrm{N}, 108.56338^{\circ} \mathrm{E}, 1000 \mathrm{~m}$ a. s. 1., on soil in middle-mountain evergreen mixed forest. 27 V 2016. A. V. Alexandrova" (LE 312527) (Crous et al., 2020).

Subfamily Leccinoideae G. Wu et Zhu L. Yang

! Ionosporus longipes (Masee) Khmeln., Davoodian, Raspé, S. M. L. Lee et Halling: "Kon Chu Rang Nature Reserve, Son Lang Commune, vicinity of waterfalls, $14.51413^{\circ} \mathrm{N}, 108.54630^{\circ} \mathrm{E}, 1000 \mathrm{~m}$ a. s. 1., on the soil in a middle-mountain evergreen mixed forest with a predominance of Podocarpaceae (Dacrydium elatum, Dacrycarpus imbricatus), Magnoliaceae, Burseraceae, Myrtaceae. 25 V 2016. O. V. Morozova" (LE 315589, fig. 2a).
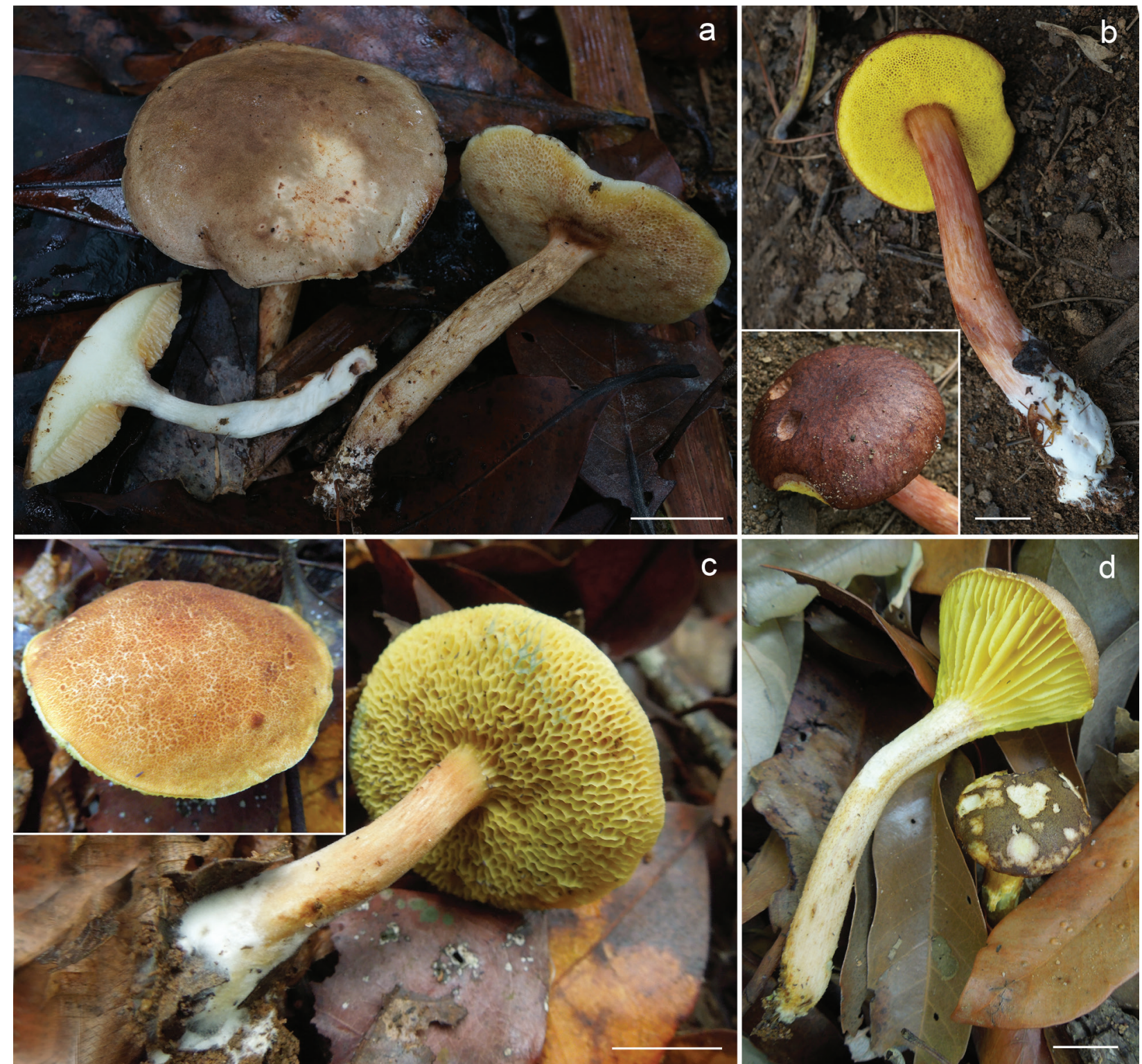

Fig. 2. Basidiomata in situ: a - Ionosporus longipes (LE 315589); b - Aureoboletus sinobadius (LE 312680); c Hourangia nigropunctata (LE 315626); d - Phylloporus luxiensis (LE 315622). 


\section{Subfamily Xerocomoideae Singer}

! Aureoboletus sinobadius Ming Zhang et T.H. Li: "Kon Ka Kinh National Park, $14.21226^{\circ} \mathrm{N}$, $108.31318^{\circ} \mathrm{E}, 1090 \mathrm{~m}$ a. s. 1., on the soil in tropical mountain polydominant forests with the participation of Myrtaceae, Meliaceae, Anacardiaceae, Fagaceae, Theaceae. 16 V 2016. A. V. Alexandrova" (LE 312680, fig. 2b).

Boletellus areolatus Hirot. Sato: "Kon Ka Kinh National Park, $14.20948^{\circ} \mathrm{N}, 108.31276^{\circ} \mathrm{E}$, $980 \mathrm{~m}$ a. s. 1., on soil in a middle-mountain evergreen broadleaf forest with the participation of families Magnoliaceae, Myrtaceae, Theaceae, Lauraceae, Fagaceae. 16 V 2016. O. V. Morozova" (LE 315577); "Kon Plong Protected Forest, Mang Canh Commune, $5 \mathrm{~km}$ north of Kondu Village, $14.72222^{\circ} \mathrm{N}, 108.316^{\circ} \mathrm{E}, 1030 \mathrm{~m}$ a. s. 1 ., on soil in a middle-mountain polydominant rainforest, 23 IV 2015. A. V. Alexandrova” (LE 315576).

! Hourangia nigropunctata (W.F. Chiu) Xue T. Zhu et Zhu L. Yang: "Kon Ka Kinh National Park, $14.222330^{\circ} \mathrm{N}, 108.310347^{\circ} \mathrm{E}, 1270 \mathrm{~m}$ a. s. 1., on the soil in a tropical mountain polydominant forest with the participation of Myrtaceae, Meliaceae, Anacardiaceae, Fagaceae, Theaceae. 20 V 2016. A. V. Alexandrova" (LE 315626, fig. 2c).

! Phylloporus luxiensis M. Zang: "Kon Ka Kinh National Park, $14.209184^{\circ} \mathrm{N}, 108.314681^{\circ} \mathrm{E}$, $1020 \mathrm{~m}$ a. s. 1., on the soil in a tropical mountain polydominant forest with a predominance of Myrtaceae, Meliaceae, Anacardiaceae, Fagaceae, Theaceae. 16 V 2016. A. V. Alexandrova" (LE 315622, fig. 2d).

Phylloporus rubiginosus M. A. Neves et Halling: "Kon Ka Kinh National Park, $14.2187^{\circ} \mathrm{N}$, $108.3168^{\circ} \mathrm{E}, 1000 \mathrm{~m}$ a. s. 1 ., on the soil in tropical middle-mountain polydominant forest dominated by Lauraceae, Myrtaceae, Meliaceae, Fagaceae, Dipterocarpaceae. 15 V 2016. O. V. Morozova" (LE 315623).

Subfamily Zangoideae G. Wu, Y. C. Li et Zhu L. Yang

Chiua viridula Y.C. Li et Zhu L. Yang: "Kon Ka Kinh National Park, $14.20791^{\circ} \mathrm{N}, 108.31500^{\circ} \mathrm{E}, 995$ $\mathrm{m}$ a. s. 1., on the soil in a middle-mountain middlemountain polydominant forest with a predominance of Myrtaceae, Meliaceae, Anacardiaceae, Fagaceae, Theaceae. 16V2016.E.S.Popov"(LE315611); "Kon Chu Rang Nature Reserve, vicinity of waterfalls, $14.51413^{\circ} \mathrm{N}, 108.54630^{\circ} \mathrm{E}, 1000 \mathrm{~m}$ a. s. 1 ., on the soil in a middle-mountain evergreen mixed forest with a predominance of Podocarpaceae (Dacrydium elatum, Dacrycarpus imbricatus), Magnoliaceae, Burseraceae (Canarium), Myrtaceae (Syzygium). 25 V 2016. O. V. Morozova" (LE 315614, fig. 3a, b); ibid. “01 VI 2016. O. V. Morozova” (LE 315612).

\section{Pulveroboletus-group}

Crocinoboletus rufoaureus (Massee) N. K. Zeng, Zhu L. Yang et G. Wu: “Kon Plong Protected Forest, $5 \mathrm{~km}$ north of Kondu Village, headwaters of the $\mathrm{La}$ and Khe rivers, $14.7455^{\circ} \mathrm{N}, 108.3019^{\circ} \mathrm{E}$, $1280 \mathrm{~m}$ a. s. 1., middle-mountain polydominant forest dominated by Podocarpaceae, Magnoliaceae, Myrtaceae, Calophyllaceae, Elaeocarpaceae, Betulaceae. 05 VI 2016. A. V. Alexandrova" (LE 315607).

! Neoboletus multipunctatus N. K. Zeng, H. Chai et S. Jiang: "Kon Ka Kinh National Park, $14.211846^{\circ} \mathrm{N}, 108.313694^{\circ} \mathrm{E}, 1080 \mathrm{~m}$ a. s. 1 ., on soil in a tropical mountain polydominant forest with the participation of Myrtaceae, Meliaceae, Anacardiaceae, Fagaceae, Theaceae. 16 V 2016. A. V. Alexandrova" (LE 315625, fig. 3c); ibid, " $14.21946^{\circ} \mathrm{N}, 108.30940^{\circ} \mathrm{E}, 1280 \mathrm{~m}$ a. s. 1.20 V 2016. A. V. Alexandrova" (LE 312474); ibid., "Krong commune, K'bang district, $14.310920^{\circ} \mathrm{N}$, $108.438320^{\circ} \mathrm{E}, 830 \mathrm{~m}$ a. s. 1., on soil in tropical middle-mountain polydominant forest with the participation Myrtaceae, Meliaceae, Anacardiaceae, Fagaceae, Theaceae. 13 V 2017. A. V. Alexandrova" (LE 315637).

Neoboletus obscureumbrinus (Hongo) N. K. Zeng, H. Chai et Zhi Q. Liang [= Sutorius obscureumbrinus (Hongo) G. Wu et Zhu L. Yang]: "Kon Ka Kinh National Park, $14.21226^{\circ} \mathrm{N}$, $108.31318^{\circ} \mathrm{E}, 1090 \mathrm{~m}$ a. s. 1., on the soil in tropical mountain polydominant forests with the participation of representatives of the families Myrtaceae, Meliaceae, Anacardiaceae, Fagaceae, Theaceae. 16 V 2016. A. V. Alexandrova" (LE 315548, fig. 3e, f).

! Pulveroboletus subrufus N.K. Zeng et Zhu L. Yang: "Kon Ka Kinh National Park, 14.21052 ${ }^{\circ}$, $108.31434^{\circ} \mathrm{E}, 1050 \mathrm{~m}$ a. s. 1 ., on the soil in a tropical mountain polydominant forest with the participation of Myrtaceae, Meliaceae, Anacardiaceae, Fagaceae, Theaceae. 16 V 2016. A. V. Alexandrova" (LE 312686, fig. 3d).

Totally, the presence of 28 species of Boletaceae in the studied area were confirmed by the molecular data (Table). Strobilomyces aff. echinocephalus, S. aff. glabriceps, and Tylopilus aff. balloui (two different lines) morphologically are close to known species but genetically not identical with the 

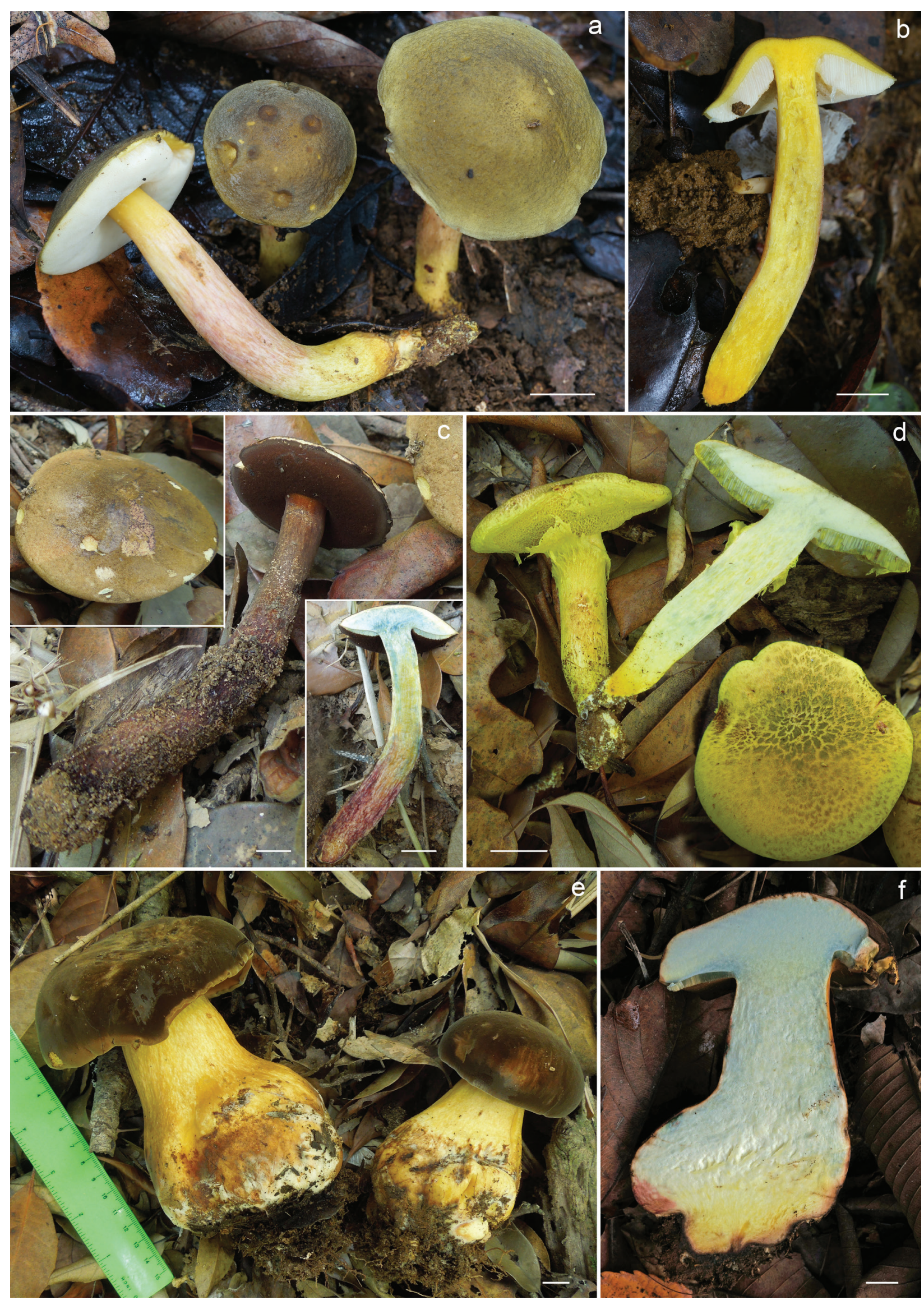

Fig. 3. Basidiomata in situ: a, b - Chiua viridula (LE 315614); c - Neoboletus multipunctatus (LE 315625); c - Pulveroboletus subrufus (LE 312686); e, f - Neoboletus obscureumbrinus (LE 315548). 
sequences kept in the NCBI GenBank. In addition, 6 more genotypes were revealed on the base of the molecular study. They could not be attributed to any known species either by molecular or morphological data; there are: Boletus sp. 1, Boletus sp. 2, Chalciporus sp. 1, Chalciporus sp. 2, Phylloporus sp. 1, Phylloporus sp. 2.

The species are distributed between 17 genera belonging to 5 subfamilies and the Pulveroboletus group. Among the territories studied, the highest diversity of boletoid species was found in the Kon Ka Kinh National Park due to the higher diversity of the communities represented there and more favorable weather conditions during the collection period. The mountain evergreen broad-leaved and coniferous-deciduous forests of this park are richest in the diversity of the Boletaceae species.

\section{Acknowledgments}

The authors are grateful to staff of the Joint Russian-Vietnamese Tropical Research and Tech- nological Center for organizing the expeditions and to management of the Kon Ka Kinh National Park, Kon Chu Rang Nature Reserve, and Kon Plong Protected Forest for their help and permission to collect in the forests. We thank Dr. E. S. Popov (Komarov Botanical Institute) for his assistance with collecting and providing literature. The study of Olga Morozova was conducted in the framework of a research project of the Komarov Botanical Institute of the Russian Academy of Sciences (no. AAAA-A18-118022090078-2) using equipment of its Core Facility Centre "Cell and Molecular Technologies in Plant Science" with the financial support of Russian Foundation for Basic Research (project no. 20-04-00349). The study of Alina Alexandrova was conducted as part of the Scientific Project of the State Order of the Government of Russian Federation to Lomonosov Moscow State University (no. 121032300081-7).

\section{REFERENCES / ЛИTEPATУPA}

Crous P. W., Cowan D. A., Maggs-Kölling G., Yilmaz N., Larsson E., Angelini C., Brandrud T. E., Dearnaley J. D. W., Dima B., Dovana F., Fechner N., García D., Gené J., Halling R. E., Houbraken J., Leonard P., Luangsaard J. J., Noisripoom W., Rea-Ireland A. E., Ševčíková H., Smyth C. W., Vizzini A., Adam J. D., Adams G. C., Alexandrova A. V., Alizadeh A., Alvarez Duarte E., Andjic V., Antonín V., Arenas F., Assabgui R., Ballarà J., Banwell A., Berraf-Tebbal A., Bhatt V. K., Bonito G., Botha W., Burgess T. I., Cabon̆ M., Calvert J., Carvalhais L. C., Courtecuisse R., Cullington P., Davoodian N., Decock C.A., Dimitrov R., Di Piazza S., Drenth A., Dumez S., Eichmeier A., Etayo J., Fernández I., Fiard J.-P., Fournier J., Fuentes-Aponte S., Ghanbary M. A. T., Ghorbani G., Giraldo A., Glushakova A. M., Gouliamova D. E., Guarro J., Halleen F., Hampe F., Hernández-Restrepo M., Iturrieta-González I., Jeppson M., Kachalkin A. V., Karimi O., Khalid A. N., Khonsanit A., Kim J. I., Kim K., Kiran M., Krisai-Greilhuber I., Kučera V., Kušan I., Langenhoven S. D., Lebel T., Lebeuf R., Liimatainen K., Linde C., Lindner D. L., Lombard L., Mahamedi A. E., Matočec N., Maxwell A., May T. W., McTaggart A. R., Meijer M., Mešić A., Mileto A. J., Miller A. N., Molia A., Mongkolsamrit S., Muñoz Cortés C., Muñoz-Mohedano J., Morte A., Morozova O. V., Mostert L., Mostowfizadeh-Ghalamfarsa R., Nagy L. G., Navarro-Ródenas A., Örstadius L., Overton B. E., Papp V., Para R., Peintner U., Pham T. H. G., Pordel A., Pošta A., Rodríguez A., Romberg M., Sandoval-Denis M., Seifert K. A., Semwal K. C., Sewall B. J., Shivas R. G., Slovák M., Smith K., Spetik M., Spies C. F. J., Syme K., Tasanathai K., Thorn R. G., Tkalčec Z., Tomashevskaya M. A., Torres-Garcia D., Ullah Z., Visagie C. M., Voitk A., Winton L. M., Groenewald J. Z. 2020. Fungal planet description sheets: 1112-1181. Persoonia 45: 251-409. DOI: $10.3767 /$ persoonia.2020.45.10

Crous P. W., Cowan D. A., Maggs-Kölling G., Yilmaz N., Thangavel R., Wingfield M. J., Noordeloos M. E., Dima B., Brandrud T. E., Jansen G. M., Morozova O. V., Vila J., Shivas R. G., Tan Y. P., Bishop-Hurley S., Lacey E., Marney T. S., Larsson E., Le Floch G., Lombard L., Nodet P., Hubka V., Alvarado P., Berraf-Tebbal A., Reyes J. D., Delgado G., Eichmeier A., Jordal J. B., Kachalkin A. V., Kubátová A., Maciá-Vicente J. G., Malysheva E. F., Papp V., Rajeshkumar K. C., Sharma A., Spetik M., Szabóová D., Tomashevskaya M. A., Abad J. A., Abad Z. G., Alexandrova A. V., Anand G., Arenas F., Ashtekar N., Balashov S., Bañares A., Baroncelli R., Bera I., Biketova A. Yu., Blomquist C.L., Boekhout T., Boertmann D., Bulyonkova T. M., Burgess T. I., Carnegie A. J., Cobo-Diaz J. F., Corriol G., Cunnington J. H., da Cruz M. O., Damm U., Davoodian N., de A. Santiago A. L. C. M., Dearnaley J., de Freitas L. W. S., Dhileepan K., Dimitrov R., Di Piazza S., Fatima S., Fuljer F., Galera H., Ghosh A., Giraldo A., Glushakova A. M., Gorczak M., Gouliamova D. E., Gramaje D., Groenewald M., Gunsch C. K., Gutiérrez A., Holdom D., Houbraken J., Ismailov A. B., Istel L., Iturriaga T., Jeppson M., Jurjević Ž., Kalinina L. B., Kapitonov V. I., Kautmanova I., Khalid A. N., Kiran M., Kiss L., Kovács A., Kurose D., Kusan I., Lad S., Laessøe T., Lee H. B., Luangsa-ard J. J., Lynch M., Mahamedi A. E., Malysheva V. F., Mateos A., Matočec N., Mešić A., 
Miller A. N., Mongkolsamrit S., Moreno G., Morte A., Mostowfizadeh-Ghalamfarsa R., Naseer A., NavarroRódenas A., Nguyen T. T. T., Noisripoom W., Ntandu J.E., Nuytinck J., Ostrý V., Pankratov T. A., Pawlowska J., Pecenka J., Pham T. H. G., Polhorský A., Posta A., Raudabaugh D. B., Reschke K., Rodríguez A., Romero M., Rooney-Latham S., Roux J., Sandoval-Denis M., Smith M. Th., Steinrucken T. V., Svetasheva T. Y., Tkalčec Z., van der Linde E. J., v.d. Vegte M., Vauras J., Verbeken A., Visagie C. M., Vitelli J. S., Volobuev S. V., Weill A., Wrzosek M., Zmitrovich I. V., Zvyagina E. A., Groenewald J. Z. 2021. Fungal Planet description sheets: 1182-1283. Persoonia 46: 313-528. DOI: 10.3767/persoonia.2021.46.11

Eames J. C., Kuznetsov A. N., Monastyrskii A. L., Hiep N. T., Truong N. Q., Quynh H. Q. 2001. A preliminary biological assessment of the Kon Plong forest complex, Kon Tum province, Vietnam. Hanoi: WWF Indochina Programme. $102 \mathrm{pp}$.

Ha T. L., Nguyen A. T., Ho T. M., Nguyen T. T., Bui V. T. 2011. Survey of the northern buff-cheeked crested gibbon (Nomascus annamensis) in Kon Ka Kinh National Park, Gia Lai Province, Vietnam. Hanoi: Fauna et Flora International; Conservation International. $21 \mathrm{pp}$.

Ha T. L., Nguyen V. H., Nguyen T. T., Tran H. V., Nguyen Ai T., Bui V. T., Nguyen T. T. 2014. Vuon quoc gia Kon Ka Kinh vung da dạng sinh học quan trong cua Tay Nguyen [Kon Ka Kinh National Park is an important biodiversity area of the Central Highlands]. Ho Chi Minh: Agriculture Publishing House. 72 pp. [In Vietnamese] (Hà Thăng Long, Nguyễn Văn Hoan, Nguyễn Thị Tịnh, Trần Hũu Vỹ, Nguyễn Aii Tâm, Bùi Văn Tuấn, Nguyễn Thị Tiên. Vườn quốc gia Kon Ka Kinh vùng đa dạng sinh học quan trọng của Tây Nguyên. Ho Chi Minh: Nxb Nông nghiệp, 2014. $72 \mathrm{tt}$.).

Hughes K. W., Petersen R. H., Lickey E. B. 2009. Using heterozygosity to estimate a percentage DNA sequence similarity for environmental species' delimitation across basidiomycete fungi. New Phytologist 182: 795-798.

Kumar S., Stecher G., Li M., Knyaz C., Tamura K. 2018. MEGA X: Molecular Evolutionary Genetics Analysis across computing platforms. Molecular Biology and Evolution 35: 1547-1549.

Le T. T., Le V. C., Tran Q. N., Tran H. M., Nguyen V. S., Monastyrskii A. L., Hayes B. D., Eames J. C. 2000. An investment plan for Kon Ka Kinh Nature Reserve, Gia Lai Province, Vietnam. A contribution to the management plan. Hanoi: BirdLife International Vietnam Programme; Forest Inventory and Planning Institute. 79 pp.

Malysheva E., Malysheva V., Alexandrova A., Morozova O. 2019. Observations on Pluteaceae in Vietnam. 1. New species and new records of Volvariella. Phytotaxa 408 (4): 233-254. DOI: 10.11646/phytotaxa.408.4.1

Malysheva E., Malysheva V., Alexandrova A., Morozova O. 2020. Observations on Pluteaceae in Vietnam. 2. One new record and ten new species of Pluteus. Phytotaxa 461 (2): 79-107. DOI: 10.11646/phytotaxa.461.2.2

Morozova O. V., Noordeloos M. E., Popov E. S., Alexandrova A. V. 2018. Three new species within the genus Entoloma (Basidiomycota, Agaricales) with clamped basidia and a serrulatum-type lamellae edge, and their phylogenetic position. Mycological Progress 17: 381-392. DOI: 10.1007/s11557-017-1364-3

New M., Lister D., Hulme M., Makin I. 2002. A high-resolution data set of surface climate over global land areas. Climate Research 21: 1-25.

Petersen R. H., Hughes K. W., Lickey E. B., Kovalenko A. E., Morozova O. V., Psurtseva N. V. 2008. A new genus, Cruentomycena, with Mycena viscidocruenta as type species. Mycotaxon 105: 119-136.

Pham T. H. G. 2020. Boletovyye griby (Boletaceae, Basidiomycota) Tsentralnogo nagorya Vyetnama [Boletoid fungi (Boletaceae, Basidiomycota) of the Central Highlands of Vietnam]. Diss. Cand. Sci. St. Petersburg. 236 pp. [In Russian] (Фам T. X. Ж. Болетовые грибы (Boletaceae, Basidiomycota) Центрального нагорья Вьетнама. Дис. ... канд. биол. наук. СПб., 2020. 236 с.).

Pham T. H. G., Morozova O. V. 2020. Boletoid fungi (Boletaceae, Basidiomycota) of the Bidoup - Nui Ba National Park (Vietnam). Turczaninowia 23, 4: 88-98. DOI: 10.14258/turczaninowia.23.4.9

Pham T. H. G., Popov E. S., Morozova O. V., Nguyen D. H. 2018. Basidiomycetous Macromycetes of the Tay Nguyen Plateau in Vietnam: The history of investigation. Mikologiya i Fitopatologiya 52(5): 306-318. [In Russian] (Фам Т. Х. Ж., Попов Е. С., Морозова О. В., Нгуен Д. Х. История изучения базидиальных макромицетов Центрального нагорья Вьетнама // Микология и фитопатология, 2018. T. 52, вып. 5. С. 306-318). DOI: 10.1134/ S0026364818050033

Pham G. H., Trinh Ð. N., Vи V. T. 2001. Survey of results of forest flora and vegetation studies in Kon Plong District, Kon Tum Province. Tap chi Khoa hoc Lam nghiep [Journal of Forestry Science] 2: 18-24. [In Vietnamese] (Phạm Gia Hội, Trịnh Dúcc Nhuần, Vũ Văn Thành. Kết quả điều tra hệ thực vật và thảm thực vật rừng huyện KonPlong, Tỉnh Kon Tum. Tạp chi Khoa học Lâm nghiệp, 2001. № 2. T. 18-24).

Sourcebook of Existing and Proposed Protected Areas in Vietnam. 2004. A. W. Tordoff, Q. B. Tran, D. T. Nguyen, M. H. Le (eds). 2nd ed. Hanoi: Birdlife International in Indochina and Ministry of Agriculture and Rural Development. CD-ROOM. URL: https://thiennhienviet.org.vn/sourcebook/source_book/index_EN.html

Taylor J. W., Jacobson D. J., Kroken S., Kasuga T., Geiser D. M., Hibbett D. S., Fisher M. C. 2000. Phylogenetic species recognition and species concepts in fungi. Fungal Genet. Biol. 31(1): 21-32. 
Thai V. T. 1978. Tham thuc vat Viet Nam (tren quan diem he sinh thai) [Forest vegetation of Vietnam (from an ecological point of view)]. Ha Noi: Publishing scientific and technical. 276 pp. [In Vietnamese] (Thái Văn Trùng. Thảm thực vật Việt Nam (trên quan điểm hệ sinh thái. Hà Nội: Nxb Khoa học và Kỹ thuật, 1978. 276 tt.).

Wu G., Feng B., Xu J., Zhu X. T., Li Y. C., Zeng N. K., Hosen M. I., Yang Z. L. 2014. Molecular phylogenetic analyses redefine seven major clades and reveal 22 new generic clades in the fungal family Boletaceae. Fungal Diversity 69: 93-115. 